\title{
NON-INSTRUMENTAL FACILITIES \\ OF LIE DETECTION AND THEIR EFFICIENCY \\ IN THE MODERN PSYCHOLOGICAL PRACTICE
}

\section{НЕІНСТРУМЕНТАЛЬНІ ЗАСОБИ ДЕТЕКЦЇ̈ БРЕХНІ ТА ЇХ ЕФЕКТИВНІСТЬ У СУЧАСНІЙ ПСИХОЛОГІЧНІЙ ПРАКТИЦІ}

\section{Katherina Vasuk ${ }^{1}$}

DOI: https://doi.org/10.30525/978-9934-588-15-0-118

Abstract. In this investigation we have analyzed theoretical and applied problems of lie detection. The main purpose of researching was proving that non-instrumental detection methods had effective. We wanted to distinguish special features of lie in the experiment. We have analyzed main modern detection methods of lie, which were divided by non-instrumental and instrumental. Most famous instrumental detection methods of lie is polygraph. Instrumental detection methods base on diagnostic of emotion, whom must accompanies lie. However, liar doesn't always feel that's why we have to use non-instrumental detection methods. They consist of non-verbal signs, which analyze gestures, facial expressions, micro expressions, and paralinguistic signs of speaking (intonation, pitch), linguistic signs. In the experiment we've researched linguistic and paralinguistic features of lie, compared these in true and lie texts. The results of experiment are evidence changing of three types of parameters. The first type is pace and rhythm, frequency and duration of pause increases, tons of voice rises. The second type involves expressive features of behavior. They are gestures, facial expressions, microexpressions, eyes moving and spatial arrangement. Theoretical analysis testifies that main feature of lie is increasing adaption gestures, especially touching the face and stereotypical movements, emblematic reservations, illustrator mismatches and speech content. It is a vexed question about eyes movements. Romanova N.M. has proved liars don't look away, but look at interlocutor. Their eyes move only

${ }^{1}$ Candidate of Psychology Science,

Assistant Professor in the Department of Psychology,

Vasyl' Stus Donetsk National University, Ukraine 
we are speaking. Additional evidences of lie are vegetative changes. They are skin color change, pulse, breath, perspiration etc. Third type of indicators is psycholinguistic indicator. They are text and related characteristics. One subtype of the psycholinguistic indicators is paralinguistic indicator. Paralinguistic indicators consist of voice tone change, accent, intonations, pace of speech. We call them tempo-rhythmic. Linguistic indicators include grammatical structure of sentences, details, logic structure of text, special word markers, plug-in constructions, quotes, speech errors. Additional way of detection is diagnostic of graphological characteristics. Such method reveals a person's tendency to lie, imagination during writing and emotional conditions in that moment. In whole correlation has revealed reliability of selected features. The main perspectives are increasing diagnostic indicators of lie, especially non-verbal, comparing methods of detection. We are going to create complex algorithm of lie detection.

\section{1. Вступ}

Людина неможлива поза комунікацією, де вона вчиться, будує стосунки, здобуває собі засоби для існування і самореалізується, тобто задовольняє переважну більшість своїх потреб. Основною проблемою в комунікації представляють деструктивні іiі форми, які створюють безліч перешкод на шляху до ефективного спілкування і взаєморозуміння. Одним з таких є брехня, тобто представлення співрозмовнику зумисне неправдивої інформації задля власної вигоди. Як з незапам'ятних часів існує брехня, так і існували спроби ії розшифровки і нейтралізації. В XX-XXI сторіччях ця проблема вийшла на рівень наукової, якою займаються фахівці з комунікацій, що закономірно мають відношення до психології.

У пошуках ефективного засобу розпізнання брехні науковці і практики вдавалися до різноманітних засобів, іноді досить екстравагантних, але в результаті шляхом відбору залишилися декілька самих надійних, які умовно можна розділити на дві категорії: інструментальні та не інструментальні. Інструментальні засоби детекції - це в основному використання поліграфу, або «детектору брехні», наукове обгрунтування якому було розроблене в працях відомого психофізіолога О.Р. Лурії. Хоча спроби зробити фіксацію фізіологічних реакцій людини під час брехні робилися дуже давно. Принцип цього засобу 
досить простий: він полягає у фіксації фізіологічних проявів емоційної реакції в ситуації, коли індивід говорить неправду, знаючи про це, тобто свідомо, що, власне і $є$ брехня. Поліграф реєструє декілька основних параметрів: частоту серцевих скорочень, артеріальний тиск, шкірно-гальванічну реакцію, особливості дихання людини, а також сучасні поліграфи можуть реєструвати міміку і зміни висоти тону. Поліграф здобув широку популярність, тому що дозволяв об'єктивно реєструвати психофізіологічні реакції індивіда. Його продовжують широко використовувати у підборі кадрів і кримінальному провадженні, не дивлячись на низку критичних застережень щодо його надійності.

Особливу проблему становить факт базування поліграфа виключно на фізіологічних реакціях, викликаних емоціями. I якщо поліграфологи шляхом відповідних процедур навчилися відрізняти звичайне хвилювання людини перед тестуванням від страху викриття брехні, то фіксувати брехню у випадках відсутності емоційної реакції поліграф нездатен. А такі випадки не рідкість. Як зазначає П. Екман, брехун може переживати страх викриття (тоді фіксуються реакції страху) або піднесення від вдалого обману (аналог радості), але все одно це емоційне реагування. Особливу складність в цьому випадку представляють особи, які не відчувають виражених емоцій під час брехні. Тому ми вважаємо, що інструментальні способи детекції набагато поступаються не інструментальним, які відрізняються, хоч і більшою суб'єктивністю, але й різноманітніші. Для практика складність полягає в тому, що кожен дослідник намагається представити власний засіб як максимально ефективний і дискредитує таким чином інші засоби, які можуть бути не менш ефективні. Практику, в свою чергу, важко перевірити методологічно правильно, експериментальним шляхом, надійність обраного засобу. 3 огляду на це, основною метою нашого дослідження була систематизація та експериментальна перевірка ефективності засобів брехні, які представлені у наукових дослідженнях психологів XX-XXI сторіччя.

Завдання дослідження полягали у наступному:

- систематизувати та скласти якомога повний перелік основних ознак брехні, які стосуються як вербальних, так і невербальних проявів;

- організувати констатувальне експериментальне дослідження, яке включає спостереження, аналіз продуктів діяльності, експертну оцінку 
і статистичну обробку отриманих показників у брехливих і правдивих повідомленнях досліджуваних:

- зробити висновок про найбільш ефективні засоби детекції.

В представленому експериментальному дослідженні ми дотримувалися основних методологічних вимог щодо проведення експерименту, сформувавши контрольну і експериментальну групу, але в нашому випадку зі зв'язаними вибірками. Ця необхідність обумовлена твердженням О. Фрая про те, що брехня не має універсальних ознак. Основний діагностичний критерій - зміна типової для індивіда поведінки. 3 огляду на це, ми намагались визначати максимально надійні параметри детекції, які зустрічаються найчастіше. Також ми враховували різноплановість самого явища брехні, бо зумисна брехня може мати 3 основні види: приховування, напівправда і повна неправда. Найскладніше для аналізу напівправда, до того ж ії важко зімітувати в експериментальних умовах, тому ми експериментально досліджували тільки повну неправду, але виділені критерії підходять частково і для виявлення приховування інформації в повідомленні.

\section{2. Невербальні засоби детекції брехні}

Під невербальними засобами детекції ми розуміємо жести (рухи рук), міміку (рухи м'язів обличчя), в тому числі і мікровирази, пантоміміку (рухи тіла), статистичні пози, рухи очей (контакт очей зі співрозмовником) жести і міміка, а також і фізіономічні засоби, коли по рисам обличчя намагаються виявити патологічного брехуна, хоча цей засіб нам видається зайвим, тому що фізіономічні показники, навіть якщо припустити їх надійність, вказують на схильність до брехні, тобто ймовірність іï прояву в поведінці, а не діагностують конкретний комунікативний акт.

Найпопулярнішими серед невербальних засобів $є$ жести, які зазвичай аналізуються профайлерами як не інструментальний засіб детекції. Жести поділяють на 3 типи: емблеми - вони позначають цілі фрази, $\epsilon$ культурно обумовленими, тому для детекції брехні не використовуються; жести-ілюстратори - підсилюють і доповнюють мовлення, основний критерій брехні - неспівпадіння ілюстраторів і змісту тексту; жестиадаптори (маніпулятори) - ї збільшення, на думку експертів з мови тіла, $€$ надійним показником брехні. Такі ідеї, зокрема представлені в працях 
відомих класиків «невербаліки», наприклад, А. Піза чи М. Бріль, збільшення жестів адаптерів свідчить про нещирість. Такої думки дотримується і відома американська профайлерка Л. Гласс, яка аналогом жестаадаптора вважає неспокійні рухи людини на стільці, переминання з ноги на ногу або прикривання рота рукою, яке часто маскують під потирання носа чи інших частин обличчя тощо. Також збільшується кількість закритих поз, особливо, коли не демонструють долоні рук (Г. Вілсон). Ми ні в якому разі не прагнемо дискредитувати дослідженні відомих науковців, але нам дуже близька позиція В. Біркенбіла, який зазначає, що жести не мають однозначного трактування. Наприклад, стиснуті кулаки свідчать як про агресивність, так і про хвилювання.

Також разом 3 жестами виділяють супутні ознаки - вегетативні зміни, наприклад, почервоніння (від сорому) чи блідий колір шкіри, зміни у диханні, тремор. Л. Гласс виділяє дихання як одну з ключових ознак брехні. У О. Фрая теж вказується ковтання слини як ознака брехні. Також у авторки зустрічається популярне твердження про жести прикривання рукою рота або інших вразливих частин тіла, як то живота, шиї, геніталій, що є теж редукцією адаптерів, може зустрічати нервовий сміх. До речі, таку ознаку ми часто спостерігали під час експерименту, про який мова буде йти нижче. Але треба бути справедливим - ці ознаки свідчить про страх і тривожне хвилювання суб' єкта, але не завжди брехня викликає страх у людини (мається на увазі страх викриття), а страх сам по собі не завжди є надійною ознакою брехні. Тому наша думка - ця ознака може бути тільки другорядною, аж ніяк не основною в детекції.

У науковій літературі іноді висувається припущення, що під час брехні люди можуть мінімізувати загальний обсяг жестикуляції, тому що брехуну не вистачає психічної енергії стежити за жестами і створювати неправдиве повідомлення. Така думка висувалась низкою дослідників: Г. Вілсона, М. Десмонда. Також буває вказівка на комбінацію двох ознак - мінімізації жестів, особливо ілюстраторів, і використання закритих жестів, наприклад, руки в кишенях. Також М. Десмонд вказував на важливість відстеження синхронності мовлення і невербальних сигналів, бо під час брехні мова тіла не відповідає змісту сказаного.

Щодо мімічних ознак, то найчастіше радять звертати увагу на очі. Наприклад, у працях Л. Гласс, А. Хея зазначається, що брехуни поси- 
люють контакт очей, бо хочуть бачити реакцію на свої слова. 3 приводу контакту очей дані дуже суперечливі. Наприклад, відомий дослідник брехні О. Фрай стверджував, що під час брехні погляд застигає, що є елементом зменшення загальної кількості рухів тіла. Однак, А. Меграбян під час свого експериментального дослідження не підтвердив жодне з припущень про особливі рухи очей, погляд або інші характеристики контакту очей. Н.М. Романова намагалась експериментально довести взаємозв'язок брехні з фізіологічними характеристиками реакцією зіниць, але дані теж виявилися неоднозначними, хоча їй вдалося довести збільшення частоти кліпання і збільшення площі руху погляду (очі «бігають»), що можливо, є ознакою стресу і активного формулювання думки. 3 впевненістю можна сказати лише про те, що міф про відведення погляду не має жодного наукового підтвердження. На жаль, спів ставити дослідження А. Меграбяна і Н.М. Романової неможливо через відмінності в умовах експерименту, можливу різницю у вибірці. Також невідомо, які емоційні стани переживали досліджувані і рівень їх майстерності у брехні. Тому однозначно прийняти цю ознаку до використання неможливо.

Також у них часто можна помітити застигле здивування 3 елементами радості, що виражається легкій асиметричній посмішці це мімічна маска радості від вдалої брехні (О. Фрай), асиметрична посмішка також вказує та презирство до жертви обману і почуття власної зверхності.

До мімічних ознак також відносять швидке моргання як ознаку тривожності. П. Екман і його учні (М. Фрізен та О. Фрай) дещо стандартизували процедуру оцінки міміки і багатократно збільшили їі надійність. П. Екман запропонував оцінювати не міміку взагалі, а мікровирази, які відрізняються від мімічної маски коротко тривалістю та меншим рівнем вираженості. Методика довела свою дієвість в питання виявленні істинної емоції індивіда, але вона також не $є$ ідеальною. Основними недоліками $\epsilon$ те, що аналізувати мікровирази краще на відеозаписі, де можна уповільнити або декілька раз переглянути зображення. У реальному спілкуванні фіксувати мікровирази надзвичайно важко, є ризик просто пропустити важливі ознаки. Також слід пам'ятати, що мікровираз свідчить не про брехню як таку, а виражає певну емоцію людини, яка ще потребує інтерпретації і віднесення іiі до можливого параметру 
брехні. М. Десмонд також вказує в детекції брехні на важливість слабких невербальних сигналів, коли вони проявляються короткий час або дуже невиражені, наче людина передумала їх демонструвати.

Таким чином, дослідники однозначно розвінчують міф про те, що брехун відводить погляд. Так можуть чинити хіба що дуже совісні люди, які брешуть вимушено, але хіба таких більшість? Також аналіз невербальних засобів детекції демонструє нам тісну прив'язку їх до емоційної сфери людини. Вони виявляють або страх викриття або радість від вдалого обману. На це ж націлений і поліграф - інструментальний засіб детекції. Але дослідники скромно замовчують той факт, що у випадку, коли суб'єкт бреше цинічно, не переживаючи ніяких емоцій, ці засоби стають недієздатними.

Труднощі в детекції створюють і культурні відмінності. М. Бутовська наголошує, що існують культурні відмінності у змісті жестикуляції і мімічних виразах, а також допустимій мірі їх прояву. Дуже суттєві відмінності існують між східними та західними країнами, тому профайлінг має етнічні обмеження, бажано, щоб детекції здійснювалася в межах своєї культури. Хоча П. Екман довів і деякі універсальні ознаки - наприклад. Мікровирази емоцій (базових) мають однаковий мімічний «малюнок» у представників різних культур, тому його методика може претендувати на універсальність застосування.

В пошуках універсальних ознак брехні дослідники часто ігнорують той факт, що люди мають жестові звички і мімічні маски, які конкретно у їх випадку не $\epsilon$ ознаками брехні. Наприклад, посмішка офіціанта це звичка, а не ознака постійної нещирості. Так само малий досвід публічних виступів в рази збільшить жести-адаптори , але ж людина при цьому говоритиме чисту правду. Може спостерігатися і зворотній ефект. Як зазначає А. Піз, людина може навчитися імітувати жестово-мімічний малюнок у спілкуванні і не витрачати на це зусиль. Цим мистецтвом володіють професійні брехуни: політики, актори, оратори, а також психопати, які мають справжній талант у цій імітації.

Також ускладнює діагностику брехні за невербальними ознаками той факт, що за ними досить точно можна діагностувати емоції людини, але ці емоції ще не можуть бути однозначним доказом брехні. Людина може боятися, але не викриття, а того, що їй не повірять. Відомий практик Є. Спіріца, який працює за системою П. Екмана, наго- 
лошує, що немає 100\% гарантованого засобу детекції, але приводить низку ознак фальшивості емоцій, які можуть слугувати доказом нещирості людини, але в чому саме, потрібне додаткове інтерв'ю. I тут ми виходимо на вербальні засоби детекції.

Таким чином, можна сформулювати 2 основні правила детекції 3 використанням невербальних кодів тіла: по-перше, не існує окремих специфічних для брехні рухів тіла, тому слід звертати увагу на нетипові для індивіда і раптові зміни цих рухів, надзвичайно виражені, або, навпаки, згладжені сигнали; по-друге, діагностично важливими $є$ невідповідність рухів і змісту мовлення, а також невідповідність сигналів різних частин тіла.

\section{3. Графологічні засоби детекції брехні}

В нашому експерименті ми не аналізували графологічні аспекти, тому що основною гіпотезою все ж було припущення про лінгвістичні ознаки як найбільш ефективні в детекції брехні. Але результати теоретичного аналізу підходів щодо цього аспекту проблеми ми все ж розглянули. В графологічних дослідженнях акцент робиться саме на сталих особистісних рисах, які виражаються в характерному написанні літер, але хоч і в незначній кількості, а представлені дослідження, спрямовані на діагностику емоційного стану за почерком.

Графологічних досліджень на тему детекції брехні надзвичайно мало. Можливо, ы дійсно, ця ознака не являється суттєво інформативною, експериментально ми ще не перевіряли надійність цих ознак, тому в даній роботі приведемо лише теоретичні викладки з цього питання. Проблеми детекції брехні за допомогою почерку найкраще висвітлені в працях Е. Ісаєвої, Ю.Г. Чернова та В. Тараненко. Враховуючи те, що через почерк аналізують сталі риси характеру, то діагностується не сам факт брехні, а схильність до неї у індивіда. Нижче приведемо ключові риси особистості, які в сукупності створюють тип особистості, схильної до брехні. Зазначимо, що як і в інших випадках, це лише вірогідні ознаки і вірогідність зростає зі збільшенням кількості цих ознак:

1. Багата уява - про неї свідчать незвичайна форма букв, великі нижні петлі.

2. Лицемірство, відчуженість - про це свідчать викривлені букви, дуже нерозбірливі, дописування елементів букв. 
3. Хитрість і підступність - надмірний загин нижніх петель вліво, постійна зміна нахилу і натиску, на лицемірство також вказує різний почерк у тексті і підписі.

4. Приховування чогось, прагнення видатись кращим - неприродно рівний і красивий почерк, перевантажений завитками і прикрашаннями, під аркадами букв є завитки.

5. Страх та розбалансований емоційний стан, що теж може бути додатковим доказом брехні видаються букви і рядки, що налізають один на один, нестабільність ознак почерку, коли один рядок пишуть 3 одним нахилом, а другий - 3 іншим або раптово змінюють написання букв, зникають завитки тощо.

6. Емоційний голод, асоціальні схильності - загострені петельки всередині відкритих букв «п», «т», верхні петлі нечіткі і перекручені, заглавні букви окремо від тексту.

7. Екстравагантність і прагнення бути в центрі уваги - виявляється такому ж нестандартному почерку, крупних буквах з завитками, також часто ставляться гачки на початку заглавних букв.

8. Також про схильність до брехні, на думку графолога П. де Сант-Коломба, свідчать такі риси особистості, як: жага влади, схильність до ризику, егоїзм, виражені матеріальні потреби, впертість, антисоціальна спрямованість особистості, ворожість, лицемірство, які діагностуються ознаками почерку.

На нашу думку, з оцінкою за допомогою графологічних ознак треба бути обережним, і враховувати їх в сукупності. Е. Чернов наголошує на мінімум 7 ознаках, що можуть свідчити хоча б про мінімальну надійність результату. Також діагностика за графологічними ознаками у практиці профайлінгу не дуже поширена, тому що діагносту рідко доводиться аналізувати написаний текст. Як правило, брехню замовляють виявити в безпосередньому спілкуванні. Але в судовій практиці і при діагностиці саме писемного повідомлення цей засіб може виявитися незамінним, тому не варто було б ним повністю нехтувати.

Непрямо можна досліджувати також і емоційні стани індивіда. Це схоже на поліграф, тільки заочний. Нами в лютому-березні 2019 р. на базі Донецького національного університету імені Василя Стуса було проведене експериментальне дослідження на виявлення особливостей почерку в різних емоційних станах. Досліджуваним (30 осіб) були 
запропоновані відеоролики, які викликали певні емоції. Було обрані сум, страх і радість. Факт зміни емоційного стану, ступінь вираження емоції та іiї вектор емоції діагностувався за допомогою опитування. Також визначалися особливості зміни настрою після перегляду відеоролика. Результати розподілилися наступним чином: настрій не змінився у $17 \%$, у 50\% він змінився на середньому рівні, а у $30 \%$ змінився суттєво. Найкраще діагностується сум, але й страх теж можна виявити за наступними ознаками: зміна розміру букв, нахилу вправо або вліво від центральної осі, зміна напрямку рядка вгору, вниз або хвилеподібно, розриви між буквами і між словами, наведення, виправлення і загальна акуратність почерку, загальний обсяг одиниць. Сила натиску в нашому дослідженні не діагностувалася через те, що не спостерігалося жодних істотних його змін в різних емоційних станах і не можливо було його достовірно дослідити. Оскільки частота вираженості ознаки була представлена у відсотках, то для статистичної обробки ми використовували q * кутове перетворення Фішера.

Результати експериментального дослідження показали, що при переживанні страху відбуваються значущі зміни почерку: в першу чергу збільшується розмір букв. Традиційно заміряють букву «р». $\varphi_{\text {емп }}=5,18$ перевищує критичне значення для рівня $\mathrm{p} \leq 0,01$. Подібний результат був виявлений і при порівнянні емоцій суму і страху $\left(\varphi_{\text {емп }}=2,04\right.$ перевищує критичне значення для рівня $\left.\mathrm{p} \leq 0,05\right)$, отже, збільшення розміру букв відбулось значно більше при емоції страху, ніж при емоції суму на рівні $\mathrm{p} \leq 0,05$.

Другою суттєвою ознакою $є$ збільшення нахилу вправо $\left(\varphi_{\text {емп }}=2,23\right.$ достовірно на рівні $\left.\mathrm{p} \leq 0,05\right)$.

Також відбувається змішення напрямку рядка від прямої лінії при переживанні будь-яких емоційних зрушень. Важливим тут $є$ напрям руху лінії. При емоції радості напрям лінії йде вгору, а при переживанні страху чи суму - стає хвилястим. Ці припущення отримали і статистичне підтвердження, бо величина $\varphi_{\text {емп }}=0,29 \epsilon$ меншою від критичного значення для рівня $\mathrm{p} \leq 0,05$.

Пр. переживанні негативних емоцій також зменшується відстань між словами, а кількість виправлень незначно, але збільшується. Таким чином, нам вдалося отримати певний перелік графологічних ознак емоційної дестабілізації індивіда, але вони можуть бути лише 
додатковими в аналізі брехні, бо навіть спів падіння схильності до брехні і емоційної дестабілізації ще не буде абсолютно точно свідчити про те, що людина говорить неправду.

Емоційні реакції не $є$ надійним засобом через те, що частина індивідів їх просто не переживає в акті брехні, а от певна побудова повідомлення є завжди. I повідомлення згадка про реальні події повинна відрізнятися від вигадки, хай і підготовленої, оскільки не спирається на реальний образ ситуації. Хоча допускаємо, що цей прийом підходить $і$ для аналізу письмового повідомлення, але не графологічного, а лінгвістичного, тобто оцінюватимуться не особливості накреслення ліній при письмі, а граматична побудова самого письмового повідомлення.

\section{4. Лінгвістичні та паралінгвістичні засоби детекції брехні}

Лінгвістичні засоби детекції, на нашу думку, більш надійні, тому що виражають спосіб мислення, описують образ, що часто не залежить від емоцій, які супроводжують процес брехні. Вітчизняний класик психолінгвістики О.Леонтьєв зазначав, що особистість людини, iii наміри, потреби і спосіб мислення завжди виражається в мовленні. Тож логічно припустити, що вигадані образи, навіть заздалегідь підготовані, будуть виражатися інакшими граматичними конструкціями, ніж образ-спогад реальної події.

Крім того, в процесі брехні-імпровізації образ треба будувати по ходу мовлення, що порушує плавність мовлення, тому у людини може збільшуватися кількість слів паразитів. Звичайно, не можна виключати, що у людини з прекрасними ораторськими здібностями цієї проблеми не буде, але таких людей надзвичайно мало.

Щодо проблеми деталізації, то тут думки дослідників розходяться. Одні, наприклад, С. Спіріца, вважають, що брехун буде ухилятися від надмірної деталізації, щоб не заплутатися у дрібницях, інші вважають, що надмірне уточнення якраз і є ознакою брехні. Наприклад, Л. Гласс вважає, що брехун неприродно розгортає речення, щоб привести більш переконливі докази, боячись, що йому не повірять. Є. Спіріца намагався примирити ці позиції припущенням, що непідготовлена брехня менш деталізована, а надмірні деталі будуть у випадку, коли людина встигла підготуватися. Але це твердження це потребує експериментальної перевірки додатково. 
Відомий практик-профайлер $€$. Спіріца пояснює фізіологічний аспект мовлення тим, що під час брехні починає домінувати ліва півкуля. Це підтверджує нашу думку про те, що лінгвістичний показник $\epsilon$ більш надійним за невербальний. Подібні зміни характеризуються появою надто логічних конструкцій, де дії в основному просто перераховуються, але через відсутність реального образу події в тексті трапляються обмовки. На цій логіці також побудований прийом слідчих, коли вони просять підозрюваного відтворити події в зворотному напрямку.

До паралінгвістичних ознак відносяться різні характеристики голосу, найчастіше вказують підвищення тональності, а також тремтіння його, що супроводжується частим відкашлюванням (Л. Гласс). Г. Вілсон також розділяє цю точку зору, додаючи, що тон при брехні втрачає виразність, стає монотонним, речитативним.

В паралінгвістичних ознаках важливу роль відіграє також інтонація. М. Біркенбіл надає їй особливого значення. В його працях вживається аналогічний термін - сигнали. Всі сигнали він поділяє на 2 категорії: сигнали змісту і ставлення. Перші сигналізують про зміст інформації, по суті це слова і жести-ілюстратори або емблеми, які супроводжують спілкування. Сигнали ставлення виражають істинне відношення людини до суті сказаного. Вони як раз і виражаються у неспівпадіння слів і жестів, адаптерах або особливих інтонаціях чи побудові фраз. До речі такий метод, як інтент-аналіз, розроблений Т.М. Ушаковою в лабораторії РАН, досліджує саме такі характеристики. Це дуже цінний діагностичний параметр в детекції брехні, оскільки невідповідність цих 2 типів сигналів є ознакою брехні. Інтенції діагностує актуальні напрямки свідомості суб'єкта, виражає його ставлення до об'єкта мовлення. Тому непрямо можна діагностувати і брехню як невідповідність реальних намірів поверховому змісту повідомлення. Ці приховані наміри діагностують на підставі аналізу всього тексту,а не окремої фрази. Наприклад, якщо індивід в тексті повсякчас вживав слова, які говорять про його негативне ставлення до об'єкту, а потім говорить фразу, що йому цей об'єкт подобається, то ці невідповідності вже $є$ свідченням брехні.

Існують серйозні протиріччя у поглядах на темп мовлення як діагностичний параметр брехні. Одні дослідники, як наприклад, Г. Вілсон та К. Макклафлін, вважають, що брехун уповільнює темп мовлення 
через проблеми із формуванням фрази, інші ж, наприклад, Є. Спіріца, С.Бернштейн, наполягають на пришвидшенні темпу мовлення з метою швидше сказати заплановану брехню. Можливо, коливання темпу в той чи інший бік індивідуальне в залежності від певних рис характеру або темпераменту, але це припущення не фігурувало в відомих нам дослідженнях і потребує окремої експериментальної перевірки.

Лінгвістичні показники брехні почали вивчатися відносно недавно в другій половині XX ст. в роботах відомого дослідника, засновника вітчизняної психолінгвістики О. Леонтьєва. На нашу думку, лінгвістичний напрямок досліджень брехні $є$ найбільш перспективним i даремно був обділений увагою практиків. Таке нехтування, вірогідно викликано ускладненнями в діагностиці цих параметрів. Вони потребують більше часу, досить глибоких філологічних знань і ретельної фіксації мовлення досліджуваного. Але переваги цього засобу також чималі. При якісному аналізі лінгвістичні параметри можуть надійно діагностувати його емоційний стан, не гірше від поліграфа і до того ж містять основні смислові категорії свідомості індивіда, виражають його світогляд. Чисто з технічної точки зору граматична побудова повідомлення-спогаду і повідомлення-імпровізації буде різною. Проаналізувавши наявні дослідження 3 цього питання, нам вдалося виділити низку показників, які можуть бути ознаками брехні. Г. Маль визначає наступні: збільшення семантично нерелевантних повторів фраз або складів, не завершення слів з наступним виправленням, самокорекції («я пішов..., тобто хотів піти...»), нелогічна перестановка слів в реченні (наприклад, «Піти на ринок мені Маша сказала» замість «Маша сказала мені пити на ринок»). Така перестановка виникає внаслідок того, що людина вигадує брехню по ходу і не встигає логічно структурувати речення, тому правдоподібні уточнення приводяться потім. Та ж сама причина сприяє виникненню мовних помилок, пауз і самокорекцій. У індивіда є один (істинний) образ ситуації, а йому потрібно описати інший, тому в свідомості виникають конкуруючи образи, які треба описати. Це провокує мовні помилки.

Конкуренція образів впливає і на морфологію мовлення. С. Борнштейн зазначає, що під час брехні зменшується кількість прикметників, відповідно речення в основі мають перевагу дієслівних і іменникових структур. Також відбувається членування речення на прості, що 
містять 2-3 синтагми. Виживається більша кількість трюїзмів і стереотипних слів, тобто не вживаються синоніми. В принципі це логічно. Вигаданий образ простіше виразити в коротких повідомленнях, де менше деталей. Трюїзми (банальні істини) заповнюють пошукові паузи між смисловими одиницями тексту.

Необхідність комплексної детекції брехні усвідомлювалась вже давно, вона спирається на необіхевіористську традицію (П. Екман, О. Фрай, Д. Мацумото, Р. Плутчик, Дж. Хессет, В. Биркенбіл, Д. Наварро та ін.), що згодом сформували профайлінг як спеціальну професію. В активну практику він був введений в 70-х pp. XX ст., але і дотепер активно не афішуються всі його надбання і знайти якісні матеріали для практичного використання і системної детекції брехні надзвичайно важко.

\section{5. Експериментальна перевірка ефективності основних засобів неінструментальної детекції}

В експериментальному дослідження за методологічну основу ми брали визначення П.К. Анохіна, що брехня $є$ різновидом функціональної системи, компоненти якої слугують досягненню корисних для суб'єкта результатів. Її компонентами є вищі психічні функції (пам'ять, увага, сприймання, мислення), а також емоції. Хоча останній не завжди $є$ вираженим. При цьому вона супроводжується відповідним гальмуванням і збудженням нервових центрів і відповідними вегетативними реакціями, про які йшлося вище.

Для діагностики ефективності основних засобів детекції брехні ми використовували брехню імпровізацію як відповіді на питання, які заздалегідь були невідомі досліджуваним. Умовою була повна неправда або правда. Порівнювалися результати 48 осіб, які повідомляли як правдиву, так і неправдиву інформацію. Для діагностики брехні ми обрали наступні 21 категорія:

- паузи - після озвучення питання, загальна частота та тривалість пауз у тексті;

- мовні помилки - обмовки, корегування слів, повтори слів;

- деталізація - відсутність деталей, схематичність тексту або надмірна деталізація, повідомлення незвичайних подробиць;

- уникання - виражені в надмірному узагальненні тексту, відходу від теми, униканні відповіді на пряме питання; 
- вставки - використання вставних конструкцій або збільшення їх кількості, використання вигуків, сленг;

- деперсоналізація тексту - виражається у використанні безособових конструкцій, згадуванні осіб без імені, а тільки їх статус чи інші соціально-демографічні характеристики;

- логічність побудови тексту - порушення логіки тексту, скорочення загальної кількості семантичних одиниць, зменшення синонімів;

- пряма мова - майже не використовується, робиться акцент на описі дій іншого.

У ході проведення дослідження нами було висунуте припущення, що описані вище ознаки можна використовувати як узагальнений профіль для детекції брехні. 3 цією метою було здійснене порівняння наявності цих ознак і зміни частоти їх прояву в одних і тих же досліджуваних в ситуації, коли вони говорять правду і брешуть. Статистична обробка даних здійснювалася за допомогою G-критерію знаків, який може використовуватися для зв'язаних вибірок. Після проведення першої частини статистичної обробки даних ми здійснили кореляційний аналіз тих показників, за якими спостерігалися значущі відмінності., щоб скласти профіль ознак для практичної детекції брехні.

При проведені першого етапу дослідження з'ясувалося, що не всі 3 визначених критеріїв виявили статистичні відмінності у ситуації правдивих і брехливих висловлювань.

Дані представлені з розрахунку 96 епізодів брехливих і стільки ж правдивих повідомлень, оскільки кожен досліджуваний діагностувався двічі.

Достовірними виявилися паузи після питання. Під час брехні зростає їх тривалість і загальна кількість пауз у тексті. Дані представлені в мілісекундах. Як бачимо, формування фальшивого образу потребує розумових затрат. Можливо, накладається і хвилювання, тому тривалість і частота пауз суттєво збільшується. Крім того, ми не створювали досліджуваним занадто стресової ситуації, де брехня могла зашкодити їх інтересам, репутації, тому у випадках, коли вона викликає страх розкриття, вважаємо, що ці реакції будуть більш вираженими, хоча це припущення потребує додаткової експериментальної перевірки.

Щодо мовних помилок, то ми зазначали в теоретичному розділі, що багато дослідників вказують на мовні помилки різного типу як 
Таблиця 1

Емпіричні показники G-критерію знаків в аналізі відмінностей ознак правдивих і брехливих повідомлень.

\begin{tabular}{|c|l|c|c|c|}
\hline № & \multicolumn{1}{|c|}{ Ознака } & $\begin{array}{c}\text { середній } \\
\text { показник } \\
\text { частоти } \\
\text { (правда) }\end{array}$ & $\begin{array}{c}\text { середній } \\
\text { показник } \\
\text { частоти } \\
\text { (брехня) }\end{array}$ & $\begin{array}{c}\text { Рівень } \\
\text { статистичної } \\
\text { достовірності } \\
\text { відмінностей }\end{array}$ \\
\hline 1 & Частота пауз & 1,006 & 1,606 & $\mathrm{p} \leq 0,05$ \\
\hline 2 & $\begin{array}{l}\text { Тривалість пауз } \\
\text { (сек.) }\end{array}$ & 0,632 & 0,816 & $\mathrm{p} \leq 0,01$ \\
\hline 3 & Корегування слів & 0,016 & 0,098 & $\mathrm{p} \leq 0,05$ \\
\hline 4 & Обмовки & 0,226 & 0,262 & недостовірно \\
\hline 5 & $\begin{array}{l}\text { Підвищення тону } \\
\text { голосу }\end{array}$ & 0,961 & 1,28 & $\mathrm{p} \leq 0,05$ \\
\hline 6 & Вигуки & 1,452 & 1,213 & $\mathrm{p} \leq 0,05$ \\
\hline 7 & Повтори слів & 1,355 & 1,803 & $\mathrm{p} \leq 0,05$ \\
\hline 8 & Синоніми & 0,065 & 0 & недостовірно \\
\hline 9 & $\begin{array}{l}\text { Безособові } \\
\text { конструкції }\end{array}$ & 0,5 & 2,566 & $\mathrm{p} \leq 0,01$ \\
\hline 10 & Вступні слова & 0,048 & 0,295 & $\mathrm{p} \leq 0,05$ \\
\hline 11 & Перехід з теми & 0,016 & 0,033 & недостовірно \\
\hline 12 & Уникання відповіді & 0,048 & 0,082 & недостовірно \\
\hline 13 & $\begin{array}{l}\text { Надмірне } \\
\text { узагальнення }\end{array}$ & 0,403 & 0,393 & недостовірно \\
\hline 14 & $\begin{array}{l}\text { Використання } \\
\text { сленгових слів }\end{array}$ & 0,145 & 0,049 & недостовірно \\
\hline 15 & $\begin{array}{l}\text { Порушення } \\
\text { логічності }\end{array}$ & 0,937 & 0,738 & $\mathrm{p} \leq 0,05$ \\
\hline 16 & $\begin{array}{l}\text { Контекстуальні } \\
\text { вставки }\end{array}$ & 0,129 & 0,147 & недостовірно \\
\hline 17 & Опис дій іншого & 0,145 & 0,279 & $\mathrm{p} \leq 0,05$ \\
\hline 18 & $\begin{array}{l}\text { Пряма мова, } \\
\text { цитування }\end{array}$ & 0,032 & 0,056 & недостовірно \\
\hline 19 & $\begin{array}{l}\text { Незвичайні } \\
\text { подробиці }\end{array}$ & 0,387 & 0,098 & $\mathrm{p} \leq 0,05$ \\
\hline 20 & $\begin{array}{l}\text { Менша кількість } \\
\text { семант. одиниць }\end{array}$ & 62,145 & 0,0605 \\
\hline 21 & Обмовки & $\begin{array}{l}\text { Надмірна чи мала } \\
\text { к-ть деталей }\end{array}$ & 0,113 & 0,01 \\
\hline 22 & & & \\
\hline
\end{tabular}


суттєві ознаки брехні, але наш експеримент цього не показав в повній мірі. Найчастіше зустрічалися корегування і повтори слів, а класичні обмовки взагалі були представлені мало і статистично значущих відмінностей не показали. В принципі і корегування слів траплялося нечасто, але статистична різниця між показниками все ж була зафіксована. Самою поширеною ознакою були повтори слів і словосполучень. Ми вважаємо, що обмовки не представлені так яскраво знову ж таки через невисокий ступінь емоційності брехні. Студенти знали, що ця ситуація експериментальна, нічим особливим їм не загрожує, тому i не виражали хвилювання.

Щодо пара лінгвістичних показників, то знайшов експериментальне підтвердження факт підвищення тону голосу під час продукування брехні. Людина починає говорити вищим тоном. При чому цей показник зустрічався у 57\% досліджуваних. Вважаємо, що у інших цей параметр просто був виражений менше, тому для достовірної фіксації потрібна була б спеціальна апаратура для аналізу голосу, але, на жаль, ми таку не використовували.

Окремо заслуговує на увагу результат аналізу особливих мовних конструкцій. До початку експерименту ми висували припущення про те, що побудова висловлювання у людини, яка бреше буде інакшою, ніж у тої, яка каже правду. Частково ця гіпотеза підтвердилася. Брешучи, людина починає набагато частіше використовувати безособові конструкції на кшталт: «Кажуть, що..» замість «я думаю», «це, звичайно, добре» замість «мені це подобається», «це трапилось несподівано», а не «Я не зміг контролювати ситуацію». Таким чином, індивід намагається дистанціюватися від предмету, говорити про який йому неприємно, хоча прямого уникання відповіді ми майже не фіксували і статистично тут немає різниці у показниках. В принципі, уникання відбувається при іншому типі брехні - приховуванні - який ми в нашому експерименті не досліджували.

Синонімічно мова у студентів бідна, бо це був розмовний стиль, але достовірно частіше при брехні використовують контекстуальні вставки і вступні слова типу: «вірогідно», «ну, я так думаю», «так би мовити» тощо. Так само рідко студенти використовують і сленг, емоційна стабільність не сприяла цьому і вони не намагалися бути надто переконливими в ситуації брехні, тому сленг логічно не використовувався. 
Також нами аналізувалася деталізація в тексті. В теорії ми розглядали низку вказівок на те, що під час брехні вона порушується кількісно. В нашому випадку ми отримали дуже високий рівень статистичної значущості відмінностей. В основному в бік збільшення деталізації. Вірогідно, таким способом особа намагається бути більш переконливою. Хоча траплявся певний типаж осіб, які зменшували кількість деталізації. В наших минулих публікаціях ми умовно називали їх екстравертованим і інтровертованим типом брехунів. Як зазначає Є. Спіріца, у брехунів є три тактики: «Зупинись», «Біжи» та «Бий». Інтровертованим притаманна перша тактика. Вони зменшують деталізацію, намагаються бути максимально лаконічними, уникати подробиць і використовують безособові конструкції.

Екстравертованим характерна друга і третя тактики, вони збільшують кількість деталей заради правдоподібності, використовують незвичайні подробиці і пряму мову, хоча остання ознака зустрічається вкрай рідко. Але не дивлячись на це розподілення за типажами, під час брехні люди намагаються говорити менше. Статистично достовірно зменшується кількість семантичних одиниць повідомлення. Як правило воно співпадає зі зменшенням деталізації.

Незвичайні подробиці частіше описують ті, хто говорить правду, вважаємо це закономірним. Людина, яка бреше, боїться проговоритись, забути подробиці, особливо, якщо вони непересічні, незвичайні, тому брехня завжди прагне бути якомога ординарною. В реальності ж трапляються і зовсім незвичайні речі, які навіть важко вигадати, тому у випадку, якщо чуєте незвичайні описи, то скоріше, це правда. Виключення можуть складати діти, які ще не бояться страху викриття і бурно фантазують. Брехня у них, як правило, спосіб самореалізації. I також патологічні брехуни демонстративного типу, які брешуть, щоб привернути до себе якомога більше уваги.

Цікавим виявився також показник порушення логічності тексту, він завищений у випадках з правдою, а не брехнею. В дійсності ми зустріли протиріччя $з$ теорією. Хоча в життєвих ситуаціях нам неодноразово доводилось бачити порушення логічності викладення матеріалу під час брехні, в експерименті такого не спостерігалося. Вважаємо, що це один з експериментальних ефектів на кшталт Хотторнського. Досліджувані знали, що приймають участь в експерименті, тому ретельно 
ставились до формування брехливого повідомлення, воно не стосувалось занадто особистої, емоційної тематики, тому не викликало сильної емоційної дестабілізації.

Таким чином, загальний поведінковий конструкт брехні у психолінгвістичному вимірі можна описати наступним чином: особистість стає менш говіркою, намагається швидше вийти з ситуації спілкування, якщо не підготувалась заздалегідь, то зменшує кількість подробиць, використовує вставні слова для виграшу часу. 3 тої ж причини зростає тривалість пауз та кількість повторів слів, підвищується тон голосу. Дистанціювання від вигаданого образу проявляється в формі вживання безособових конструкцій і опису дій іншого, а не своїх.

Таким чином, можна зробити висновок, що не всі задані нами психолінгвістичні особливості є ефективними у виявленні правдивих чи брехливих висловлювань, так як підтвердилось тільки 12 з 22 критеріїв. До того ж існують декілька типажів брехунів, комплексні ознаки поведінки яких суттєво розрізняються. Для уникнення помилок під час практичної детекції, за порадою Є. Спіріци, потрібно враховувати сукупність ознак, щоб їх було не менше трьох.

\section{6. Проблема комплексного підходу у виборі засобів детекції брехні}

Як зазначає Є.С. Центров, поведінка під час брехні, їі мотиви і частота взагалі формуються під впливом багатьох соціокультурних чинників, тому у кожної людини профіль поведінкових ознак брехні сильно варіює. Але в межах поведінки одного індивіда цей набір показників дуже стабільний, тому ми так легко розпізнаємо брехню у добре знайомих людей.

О. Фрай також наголошував на відсутності специфічних саме для брехні ознак. Єдина спільна закономірність - різка зміна звичних поведінкових паттернів. В цьому і полягає складність детекції, бо для надійної діагностики потрібно проводити первинну специфікацію, тобто знати поведінку людини в ситуації, коли вона говорить правду.

На нашу думку, специфічні ознаки брехні все ж існують, але основна помилка практиків в тому, що вони шукали 1-2 ознаки, які б гарантували їм надійний результат. Наш підхід полягає в тому, що потрібно співвідносити невербальні, лінгвістичні і пара лінгвістичні 
ознаки, основними 3 яких все ж будуть лінгвістичні. Наш статистичний аналіз показав, що ознаки брехні утворюють своєрідні кластери, в середині яких існують кореляційні залежності між параметрами брехні. Провівши кореляційний аналіз за допомогою критерію лінійної кореляції Пірсона, ми з'ясували наступне: під час брехливого повідомлення пропорційно частоті зростає і тривалість пауз, а також кількість вигуків. Тобто людина починає запинатися, що говорить про єдиний клас поведінкових ознак.

Другий тип поведінки під час брехні - це збільшення деталізації і паралельно кількості повторів, опису дій інших і цитувань. Тобто особистість, якій характерна ця поведінка намагається якомога більше деталізувати, щоб виглядати правдоподібним. Як правило, це характерно для людей з розвиненим мовленням, гарними ораторськими здібностями.

Третьою стратегією поведінки було уникання, воно характеризується зміною теми, ухилянням від відповіді, надмірним узагальненням і корекцією слів, також часто спостерігалися контекстуальні вставки. Тобто індивід у цьому випадку намагається швидше завершити спілкування. Вважаємо, що такий тип поведінки притаманний брехні-приховуванню, хоча це припущення додатково експериментально не перевірялось.

\section{7. Висновки}

На основі теоретичного аналізу нами було виділено різні типи ознак брехні, які можуть бути використані у практичній детекції. Серед них: невербальні, що включають жести, міміку, мікровирази, рухи очей і розташування співрозмовників; психофізіологічні - зміна кольору шкірних покривів, частоти пульсу, дихання, потовиділення тощо; паралінгвістичні - зміна тону голосу, наголосів, інтонацій, темпу мовлення; лінгвістичні - граматична будова речення, деталізація, логічна будова тексту, наявність спеціальних слів-маркерів, вставних конструкцій, цитувань і узагальнень, незвичайних подробиць, мовних помилок. Також додатковим способом детекції є діагностика графологічних характеристик почерку людини.

Експеримент показав, що невербальні засоби детекції менш надійні, ніж вербальні, в першу чергу тому, що діагностують емоційні реакції людини, які не є специфічним для брехні, а іноді взагалі відсутні. 3 тієї ж причини сумнівною $є$ і тестування на поліграфі. 
В ході експерименту було спростовано припущення про ефективність деяких психолінгвістичних особливостей у детекції брехливих висловлювань на практиці таких як: контекстуальні вставки, наявність обмовок, відсутність деталей. Не всі психолінгвістичні особливості вказують на правдивість чи брехливість висловлювання, навіть навпаки один і той самий показник може вказувати на протилежні ознаки.

Були виділені кластери ознак, які грунтуються на наступних показниках: зміни деталізації, різні засоби уникання діалогу, темпо-ритмічні характеристики мовлення, що супроводжуються зміною висоти тону. В перспективі обов'язково потрібне розширена діагностика комплексу ознак з урахуванням інших типів ознак, особливо невербальних, а також порівняння ефективності поліграфа і не інструментальних засобів детекції у одних і тих же досліджуваних. Це дозволить створити комплексний алгоритм детекції, який би включав всі означені вище засоби. Практично корисним було б створення типології брехунів і їх індивідуального профілю ознак.

\section{Список літератури:}

1. Алексеев Л.Г. Психофизиология детекции лжи. Методология. Москва, 2011. $108 \mathrm{c}$.

2. Белянин В.П. Психолингвистика. Москва, 2004. 232 с.

3. Биркенбилл М. Язык интонации, мимики, жестов. Санкт-Петербург, 1997. $224 \mathrm{c}$.

4. Бриль М. Читаем язык жестов. Санкт-Петербург, 2010. 159 с.

5. Гласс Л.Все лгут: как выявить обман по мимике и жестам. Москва, 2014. $236 \mathrm{c}$.

6. Гольдберг И Язык почерка или проблемы на бумаге. Москва, 2009. 127 с.

7. Десмонд М. Библия языка телодвижений. Москва, 2010. 241 с.

8. Засєкіна Л.В. Тенденції розвитку вітчизняної психолінгвістики: методологічний огляд проблем та окреслення шляхів їх вирішення. Психолінгвістика. 2008. Вип. 1. URL: http://nbuv.gov.ua/UJRN/psling_2008_1_2

9. Исаева Е.Л Практическая графология или как узнать характер по почерку. Москва, 2010. 256 с.

10. Майорчак Н.М. Соціально-психологічні особливості прояву брехливості особистості: дис. кан. психол. наук: 19.00.05 / Майорчак Наталя Миколаївна. Сєвєродонецьк, 2017. 223 с.

11. Ковалев П.А. Роль графологической теории в судебном почерковедении. Исторические, философские, политические и юридические науки, культурология и искусствоведение: вопросы теории и практики. Тамбов. 2016. № 4(66). Ч. 2. С. 71-75. 
12. Лабунская В.А. Психология експресивного поведения. Москва : Знание, 1989. 64 с.

13. Леонтьев А.А. Основы психолингвистики. Москва : Смысл, Академия, 1999. $288 \mathrm{c}$.

14. Пиз А., Пиз Б. Язык телодвижений. Москва, 2009. 464 с.

15. Повстяний О.В. Історичний процес створення та впровадження застосування поліграфа в оперативно-розшукову діяльність правоохоронних органів України. Науковий вісник Львівського держсавного університету внутрішніх справ. 2015. № 2. С. 313-322.

16. Поповичев С.В. Легко солгать тяжело. Москва, 2011. 399 с.

17. Романова Н.В. Психолінгвістичні методи дослідження емотивної лексики. Наукові записки [Національного університету «Острозька академія»]. Сер. : Філологічна. 2012. Вип. 29. С. 176-179.

18. Фрай О. Три способа выявления лжи: как читать мысли лжеца, как обмануть детектор лжи. Санкт-Петербург, 2006. 286 с.

19. Чернов Ю.Г. Анализ почерка: Системный подход с приложением в психологии, криминалистике и других областях. Москва : Генезис, 2011. 358 с.

20. Экман П. Психология лжи. СПб. : «Питер», 1999. 272 с.

21. Wilson G., MacLaughlin C. Winning with Body Language. Bloomsbury. $2001.213 \mathrm{p}$.

\section{References:}

1. Alekseev L.G. (2011). Psikhofiziologiya detektsii lzhi. Metodologiya [Psychophisiology of lie detection. Methodology]. Moskow: Illigar. (in Russian)

2. Belyanin V.P. (2004). Psikholingvistika [Psycholinguistics]. Moskow: Moskow psychology-social institute. (in Russian)

3. Birkenbill M. (1997). Yazyk intonatsii, mimiki, zhestov [Thelanguadge of intonation, facial expression, moves]. Sankt-Peterburg: Piter. (in Russian)

4. Bril' M. (2010). Chitaem yazyk zhestov [Reading of moves language]. Sankt-Peterburg: Piter. (in Russian)

5. Glass L. (2014). Vse lgut: [The all lie] Moskow: Alpina non-fiction. (in Russian)

6. Gol'dberg I (2009). Yazyk pocherka ili problemy na bumage [Handwriting language or a problem on paper]. Moskow: ACT. (in Russian)

7. Desmond M. (2010). Bibliya yazyka telodvizheniy [The bible of moves languadge]. Moskow: EKSMO. (in Russian)

8. Zasyekina L.V. (2008). Tendentsiyi rozvytku vitchyznyanoyi psykholinhvistyky: metodolohichnyy ohlyad problem ta okreslennya shlyakhiv yikh vyrishennya [The development trendsof domestic psycholinguistic: methodology overview of problems and its solutions] Psykholinhvistyka.Pereyaslav-Khmelnitsky. URL: http://nbuv.gov.ua/UJRN/psling_2008_1_2 (in Russian)

9. Isaeva E.L (2010). Praktichesḱaya grafologiya ili kak uznat' kharakter po pocherku [Practical graphology, or how to determine character by handwriting]. Moskow: ACT. (in Russian) 
10. Mayorchak N.M. (2017). Sotsial'no-psykholohichni osoblyvosti proyavu brekhlyvosti osobystosti [socio-psychological characteristics of personal falsehood] (PhD Thesis), Syevyerodonets'k. (in Ukranian)

11. Kovalev P.A. (2016). Rol' grafologicheskoy teorii v sudebnom pocherkovedenii. [The graphological theory in judicial handwriting]. Tambov, pp. 71-75. (in Russian)

12. Labunskaya V.A. (1989). Psikhologiya ekspresivnogo povedeniya [The psychology of expression behavior]. Moskow: Znanie. (in Russian)

13. Leont'ev A.A. (1999). Osnovy psikholingvistiki [The basics of psycholinguistic]. Moskow: Smysl. (in Russian)

14. Piz A., Piz B. (2009). Yazyk telodvizheniy [The body languadge]. Moskow: EKSMO. (in Russian)

15. Povstyanyy O.V. (2015). Istorychnyy protses stvorennya ta vprovadzhennya zastosuvannya polihrafa $\mathrm{v}$ operatyvno-rozshukovu diyal'nist' pravookhoronnykh orhaniv Ukrayiny [The hystorical prosess of making and introduction a polygraph in operational investigative activities of Ukrain poilice]. Naukovyy visnyk L'vivs'koho derzhavnoho universytetu vnutrishnikh sprav. Lviv, pp. 313-322. (in Ukranian)

16. Popovichev S.V. (2011). Legko solgat' tyazhelo [Easily to lie hardly] Moskow. (in Russian)

17. Romanova N.V. (2012). Psykholinhvistychni metody doslidzhennya emotyvnoyi leksyky [Psycholinguistical method of researching of emotion lecsik] Naukovi zapysky [Natsional'noho universytetu "Ostroz'ka akademiya"]. Ser.: Filolohichna. Ostroh, pp. 176-179. (in Ukranian)

18. Fray O. (2006). Tri sposoba vyyavleniya lzhi: kak chitat' mysli lzhetsa, kak obmanut' detektor lzhi [three methods of lie detection]. Sankt-Peterburg: Piter. (in Russian)

19. Chernov Yu.G. (2011). Analiz pocherka: Sistemnyy podkhod s prilozheniem $v$ psikhologii, kriminalistike i drugikh oblastyakh [Analysis of handwriting: systems approach with applying in psychology, criminalistic and other science]. Moskow: Genezis. (in Russian)

20. Ekman P. (1999). Psikhologiya lzhi [The psychology of lie]. SanktPeterburg: Piter. (in Russian)

21. Wilson G., MacLaughlin C. (2001).Winning with Body Language. Bloomsbury. 